\title{
ДОКТРИНАЛЬНІ ПІДХОДИ ДО ВИЗНАЧЕННЯ ПОНЯТТЯ ПУБЛІЧНОГО АДМІНІСТРУВАННЯ
}

Даниленко А. О.

Для того щоб зрозуміти який науковий підхід до дифініювання терміну «публічне адміністрування» $\epsilon$ найбільш прийнятним для сучасного етапу розвитку вітчизняної адміністративної науки, правотворчості та правореалізації зокрема, здійснено огляд наукових джерел, присвячених цій та суміжній тематикам. Автором підтримано позицію широкого трактування цього процесу та сформовано авторське категорійно-понятійне його розуміння.

Ключові слова: влада, держава, публічне адміністрування, публічне управління, суспільство.

Для того чтобы понять какой научный подход к определению термина «публичное администрирование» является наиболее приемлемым для современного этапа развития отечественной административной науки, правотворчества и правореализации в частности, сделан обзор научных источников, посвященных этой и смежной тематикам. Автором поддержана позиция широкой трактовки данного процесса и сформировано авторское категорийно-понятийное его понимание.

Ключевые слова: власть, государство, публичное администрирование, публичное управление, общество.

The aim of this article is an analysis of doctrinal approaches to defining the concept of public administration. This done in order to understand which scientific approach to the definition of term is most appropriate for current stage development of national administrative science, lawmaking and legal implementation.

Actual problems of public administration have been the subject of research by many scientists, but despite their considerable achievements, the stated problems do not lose their relevance.

The main problem is that the doctrine of legal science regarding the categorical conceptual understanding of the same phenomenon or process contains at least several positions and sometimes hundreds. It depends on the legal nature of the phenomenon under study. The unanimity of the positions of scientists can be observed only in the case of legislative consolidation of its basic structural properties or individual essential features, which is the basis of its content content. Otherwise, there is a subjective interpretation of a particular scientist, expressed by the aggregate representation of a certain ideological content.

The reasons for this state of affairs can be distinguished by at least several, starting with the absence of official (legislative) interpretation of these categories, ending with a hyper complex of features of this process, which has an uncertain structure and strategic dynamics.

Having reviewed the scientific sources devoted to this and related topics, the author supported the position of a broad interpretation of this process and formed the author's categorical and conceptual understanding of it. In the essential dimension of public administration is the cooperation of the efforts of the subjects of administrative legal relations, expressed as a joint activity for the achievement of public goals.

Key words: power, public administration, public services, society, state.
Постановка проблеми та її актуальність. Доктрина юридичної науки щодо категорійно-понятійного розуміння одного і того ж явища чи процесу містить щонайменше декілька позицій. Це залежить від юридичної природи досліджуваного феномену. Одностайність позицій вчених можна спостерігати лише у разі законодавчого закріплення основних його конструкційних властивостей або ж окремих сутнісних ознак, що $є$ базисом його змістового наповнення. У іншому разі має місце суб'єктивне інтерпретування конкретного науковця, виражене сукупним уявленням певного ідейного змісту.

Зазначене стосується і категорії «публічне адміністрування», яка, незважаючи на активне дослідження та застосування вченими, на думку багатьох із них, досі не має певного однозначного трактування. Зараз дуже популярно і модно вживати нові терміни, хоча, за словами вчених, мало хто може достовірно сказати і обґрунтувати різницю між публічним та державним управлінням, публічним і державним адмініструванням, управлінням та адмініструванням, публічною та державною адміністрацією [1, с. 113].

Причин такого стану речей можна виділити щонайменше декілька, починаючи з відсутності офіційного (законодавчого) трактування зазначених категорій, закінчуючи гіперкомплексом ознак цього процесу, яке має невизначену структуру та стратегічну динаміку. Відповідно, для того щоб зрозуміти який науковий підхід до дифініювання зазначеного терміну є найбільш прийнятним для сучасного етапу розвитку вітчизняної адміністративної науки, правотворчості та правореалізації зокрема, вважаємо за доцільне здійснити огляд наукових джерел, присвячених цій та суміжній тематикам.

Аналіз останніх досліджень і публікацій. Окремі проблеми публічного адміністрування були предметом дослідження таких вчених, як О. Амосов, В. Бех, В. Воронкова, В. Дзюндзюк, Г. Зинченко, К. Колесникова, О. Кузьменко, О. Лазор, М. Максименюк, В. Малиновський, О. Митяй, П. Петровський, В. Пилипишин, Т. Семенчук, та інші. Однак, незважаючи на значні здобутки вчених, заявлена проблематика не втрачає своєї актуальності.

Метою цієї статті $\epsilon$ аналіз доктринальних підходів до визначення поняття публічного адміністрування.

Виклад основного матеріалу. За справедливими твердженнями О. Митяя та О. Світового, державне управління $є$ одним із найскладніших інститутів і категорій адміністративного права у зв'язку з комплексним характером, специфікою суб'єктів і об'єктів державного управління і взаємозв'язків між ними. Трансформаційні процеси, що відбуваються в українській державі і суспільстві, адміністративна реформа, що триває, зумовили науковий пошук нових підходів до розуміння 
суті державного управління і можливостей його оновлення, що виразилося в підвищенні уваги до такої категорії, як «публічне адміністрування»[2, с. 124].

На переконання більшості вчених, державне управління реформується в публічне [3, с. 21]. Тому часто в науці й на практиці як рівноцінний замінник терміна «управління» застосовують слово «адміністрація», причому йдеться не про керівництво якогось органу чи організації, а про власне процес здійснення управління (адміністрування) [4, с. 192].

Вчений В. Дзюндзюк, аналізуючи необхідність переходу від публічного адміністрування до публічного менеджменту, виявив, що термін «адміністрування» походить від ministrare, що означає «служити». Дослідник вказує, що оксфордський словник визначає його як «управління справами» чи «спрямування або керівництво виконання» [5] (словник Вебстера дає, власне кажучи, те ж саме визначення [6]) [7, с. 9]. Згідно з результатами дослідження Т. Семенчука під цим терміном зазвичай розуміється організаційно-розпорядчий метод державного управління, який використовується органами державної влади. Іншими словами, адміністрування - це бюрократичний метод управління суспільством, що ґрунтується на силі та авторитеті влади, тобто в наказах, постановах, розпорядженнях, вказівках та інструкціях. Цей метод $\epsilon$ специфічним, та його переважно використовують виконавчі органи влади в особі державних службовців. Тобто, на думку автора, адміністрування - це дії державних службовців у частині надання громадянам країни послуг щодо чинного законодавства [8, с. 387].

Здебільшого зарубіжні вчені вважають, що саме адміністрування $€$ тим керівним процесом, який впливає на публічний та приватний сектори. Відповідно, публічне адміністрування - його різновид, секторна приналежність, яка навіть назвою репрезентує орієнтацію на загальне благо.

К. Колесникова наголошує, що зазначена категорія пішла із зарубіжної літератури. Спочатку переклад терміну "Public administration” був однозначним - «державне управління», згодом було досліджено, що це поняття має полісемантичний характер і залежно від контексту перекладається ще як «публічне адміністрування» та «публічна адміністрація» і навіть «суспільне управління», «управління на державному та місцевому рівні», «громадська адміністрація». Це стосується і термінів "public" i “administration”. У словнику Мюллера надано п'ять дефініцій “public” як прикметника: суспільний, державний; народний, загальнонародний; публічний, загальнодоступний; комунальний; відкритий, гласний [9], а в професійному онлайн-словнику Мультітран - 15: суспільний, народний, загальнонародний, комунальний, публічний, загальнодоступний, відкритий, державний, загальний, казенний, суспільного користування, колективний, гласний, несекретний, об'єднаний [1, с. 113; 10].

Річ у тім, що в англійській мові відсутня різниця між словами «державний» $\mathbf{i}$ «суспільний»: обидва ці слова виражені терміном “public". Це $\epsilon$ показовим, тому що держава - це не тільки чиновники і політики, держава і влада - це суспільство, яке впливає на процеси, які відбуваються у країні. Школа публічної політики ставить своєю метою вдосконалення того, що називається “policy”, а не “politics”. "Public policy” передбачає узгодження суспільних інтересів, а не боротьбу чи конкуренцію, і цим вона принципово відрізняється від партійної політики. Public policy передбачає сумісну роботу представників уряду, місцевих влад, суспільних організацій, незалежних дослідників, експертів тощо, а не протиставлення їх один одному. Public policy здійснюється за рахунок розгортання процесу аналізу державної політики як єдності економічної, соціальної і політичної сфер, спрямованих на вирішення суспільно-значущих проблем [11; 12; 13, с. 51-52].

Відповідно, у сутнісному вимірі публічним адмініструванням $\epsilon$ кооперація зусиль суб'єктів адміністративних правовідносин, виражена спільною діяльністю для досягнення публічних цілей.

У вигляді наступної системи вкажемо окремі наукові позиції відносно визначення поняття публічного адміністрування:

1) Т. Семенчук пропонує розглядати публічне адміністрування як механізм, який, з одного боку, забезпечує надання суспільству послуг щодо законодавства, а з іншого - реалізацію обраного типу політики, яку втілюють державні службовці, яким було делеговано повноваження під час волевиявлення народу на виборах, як в межах країни, так і за кордоном, у всіх напрямах їі прояву [8, с. 388];

2) О. Амосов та Н. Гавкалова публічне адміністрування визначають як взаємовплив суб'єкта управління та носія влади на суспільні процеси та відносини відповідно до суспільно-значущих функцій і повноважень. Вчені стверджують, що аналізований процес має подвійну філософську природу, оскільки може розглядатись як: 1) професійна діяльність державних службовців, яка охоплює всі види діяльності, спрямовані на реалізацію рішень уряду, а також вивчення, розробка і впровадження напрямів державної політики; 2) система управління, представлена адміністративними інститутами в рамках прийнятої структури влади [14, с. 7];

3) мінімалістично, однак досить коректно досліджуваний феномен розкриває О. Кузьменко, яка вважає, що це діяльність публічної адміністрації щодо задоволення загальних публічних інтересів соціуму [15, с. 24];

4) Г. Зінченко вважає, що система публічного адміністрування - це організаційні структури державного апарату, персонал яких реалізує сукупність необхідних функцій, використовуючи при цьому комплекс відповідних форм, методів і процедур, а також прямі та зворотні зв'язки між державою та суспільством [1, с. 114; 16$, c. 46$]$;

5) на думку В. Коваленка, публічне адміністрування розкриває основні напрями цілеспрямованої діяльності суб'єктів владних повноважень щодо виконання адміністративних зобов' язань [1, с. 114; 17, с. 214];

6) дещо інакше визначає публічне адміністрування В. Бех. Дослідник вважає, що це суспільно-політична влада, основні види якої: а) влада народу як безпосереднє народовладдя, безпосередня демократія (вибори, референдуми); б) державна влада - законодавча, виконавча, судова; в) місцеве самоврядування - місцева публічна влада, що здійснюється, зокрема, територіальними громадами, представницькими органами місцевого самоврядування - місцева, публічна влада, що здійснюється, зокрема, територіальними громадами, представницькими органами місцевого самоврядування (радами), виконавчими органами рад - сільськими, 
селищними, міськими головами тощо. Уточнено, що термін «публічна влада» аналогічний в той же час терміну «народовладдя» чи врядування [11, с. 208; 18];

7) вчена К. Колесникова публічне адміністрування вважає складником публічного врядування та процедурою втілення рішень, прийнятих у системі публічного управління [1, с. 117];

8) за твердженнями О. Лазор, аналізований процес це діяльність усієї системи адміністративних інституцій $з$ ієрархією державної влади та влади місцевого самоврядування. Тобто це скоординовані групові дії з питань публічних справ, спрямовані на їх вирішення [19, с. 114].

При цьому маємо змогу спостерігати як певну єдність думок вчених, так і їх неузгодженість. Яскраво це можна продемонструвати відсутністю їх узгодженої позиції й щодо таких термінів, як «публічна адміністрація», «адміністративні інститути» чи «публічні справи». 3 наявного можна зробити логічний висновок про те, що аналізований процес має два полярних аспекти: 1) діяльність винятково представників виконавчих органів влади - виконання чи забезпечення державної політики; реалізація урядом покладених на нього функцій; 2) діяльність невичерпного кола уповноважених державою суб'єктів задля виконання функцій останньої.

Тобто у вузькому значенні публічне адміністрування пов'язане з виконавчою гілкою влади та розглядається як професійна діяльність державних службовців та осіб, що працюють у соціальній сфері, у неурядових організаціях, в установах та в організаціях, що мають бюджетне фінансування та існують на спонсорські кошти з метою забезпечення життєдіяльності країни на рівні державного, регіонального, місцевого управління та здійснюють вивчення, розробку і впровадження публічної політики. Публічне адміністрування у широкому сенсі пов'язане з функціонуванням всіх гілок влади - законодавчої, виконавчої, судової [20, с. 12]. Таким чином, у змісті робиться ототожнення державно-адміністративного управління з процесом здійснення відповідної діяльності, тобто з широким тлумаченням публічного адміністрування як особливого та самостійного різновиду діяльності державних органів, в тому числі органів виконавчої влади. 3 цим моментом безпосередньо пов'язаний і адміністративний аспект адміністрування [21, с. 67].

Висновки. Підводячи підсумок, можемо констатувати, що публічне адміністрування, на наш погляд, слід розглядати саме з позиції широкого трактування цього процесу, що зумовлюється наступним: публічне адміністрування діє у всіх формах державної влади (не лише виконавчої, але й законодавчої - через публічний характер нормотворчості, судової - через публічне становище суддів, функціонування органів суддівського врядування та інших суб'єктів, що здійснюють судове адміністрування), тому публічне адміністрування $\epsilon$ всеохоплюючим поняттям, керівним процесом держави, реалізованим за допомогою публічного формування, впровадження та використання загальних та спеціальних норм, інструментів та процедур задля врегулювання суспільних відносин та виконання поставлених перед державою та суспільством завдань та функцій.

\section{Література}

1. Колесникова К.О. Публічне адміністрування в Україні: огляд літературних джерел. Теорія та практика державного управління. 2013. Вип. 3. С. 112-119.

2. Митяй О.В. Дослідження понять «державне управління» $\mathrm{i}$ «публічне адміністрування». Держава та регіони. Серія: Державне управління. 2018. Вип. 1. С. 124-128.

3. Петровський П.М. Проблема розуміння в контексті розвитку публічного управління в Україні. Ефективність державного управління. 2017. Вип. 1. С. 21-27.

4. Малиновський В.Я. Державне управління : навч. посіб. 2-ге вид., доповн. та переробл. Київ : Атіка, 2003. $576 \mathrm{C}$. 1991

5. Oxford Dictionary. Oxford : Oxford University Press,

6. Hughes 0. Public Management and Administration: An Introduction. London : Macmillan Press Ltd, 2005.

7. Дзюндзюк В.Б. Модернізація органів влади: перехід від публічного адміністрування до публічного менеджменту. Актуальні проблеми державного управління. 2009. № 2. С. 9-14.

8. Семенчук Т.Б. Сутність категорії «публічне адміністрування» та передумови ії формування. Вісник економіки транспорту і промисловості. 2013. Вип. 42. С. 385-390.

9. Термін «публічний». Англо-російський словник Мюллера. URL: http://slovarus.info/eng_m.php.

10. Термін «публічний». Онлайн-словник Мультітран. URL: http: //www.multitran.ru/c/M.exe?l1=2\&l2= $1 \& \mathrm{~s}=$ public.

11. Максименюк М.Ю. Філософські засади публічного адміністрування. Гуманітарний вісник Запорізької державної інженерної академії. 2015. Вип. 61. С. 206-223.

12. Воронкова В.Г. Філософія гуманістичного менеджменту: (соцально-антропологічні виміри) : монографія. Запоріжжя : РВВ ЗДІА, 2008. 254 с.

13. Сукманова О.В. Публічне адміністрування охорони права власності в Україні. Теорія і практика. Херсон : ОЛДІ-ПЛЮС, 2019. 450 с.

14. Амосов О. Моделі публічного адміністрування (архетипова парадигма). Публічне управління: теорія та практика. 2013. Спец. вип. С. 6-13.

15. Кузьменко О.В. Правова детермінація поняття «публічне адміністрування». Юридичний вісник. Повітряне і космічне право. 2009. № 3. С. 20-24.

16. Зинченко Г.П. Социология управления: Учебно-метод. Комплекс. Ростов-на-Дону : СКАГС, 2010. 48 с.

17. Колпаков В. К. Курс адміністративного права України : підручник. Київ : Юрінком Інтер, 2012. 808 с.

18. Бех В.П. Генезис соціального організму країни : монографія. 2-е вид. Запоріжжя : Просвіта, 2000. 288 с.

19. Лазор О.Я. Публічне управління та адміністрування: ретроспектива деяких теоретичних аспектів. Університетські наукові записки. 2015. № 4. С. 111-121.

20. Амосов О.Ю. Публічне адміністрування: методологічний контекст. Публічне управління XXI столітmя: від соціального діалогу до суспільного консенсусу : зб. тез до XIV Міжнар. наук. конгресу. Харків : Вид-во ХарРІ НАДУ «Магістр", 2014. С. 12-13.

21. Пилипишин В.П. Адміністративний аспект публічного адміністрування. Наукові записки Інституту законодавства Верховної Ради України. 2015. № 6. С. 68-71.

Даниленко А. О., аспірант, науковий співробітник Науково-дослідного інституту публічного права 